\title{
Stages of territorial configuration in the non-planned occupation of the Huerta de Murcia, 1929-2015
}

\author{
Marcos Ros Sempere, Fernando M. García Martín \\ Escuela Técnica Superior de Arquitectura y Edificación, \\ Universidad Politécnica de Cartagena (UPCT), Cartagena, Spain \\ E-mail:marcos.ros@upct.es, fernando.garcia@upct.es
}

\begin{abstract}
The "Huerta de Murcia" is an agricultural area of about 10,000 Ha in size, originated in the ninth century, and linked to an extensive network of canals dependent from Segura River. Such system provides a much divided and fragmented agrarian morphology, around the city of Murcia, in the southeast of Spain, basically dedicated to the agriculture. The city of Murcia has experimented an important growth in the last five decades, substituting hundreds of hectares of agrarian land, into urban. But even more important than this, the periurban area has suffered along the past 90 years a periurbanization process, caused by the unscheduled appearance of buildings. Most of them have emerged in the last 4 decades, whose use is mainly family housing and holyday homes, and have not been planned by standard planning procedures. This causes a spontaneous phenomenon of dispersed territory occupation. The paper shows, through an analysis methodology based on orto-photographical series and cadastral data, the existence of different stages along the studied period (1929-2015). These stages are substantially different each other in two ways: the patterns and zones affected by this process, on one hand, and the intensity of this process, which vary along each studied period, on the other hand. The analysis of these patterns, as well as a proposed classification, and the quantification of the process in each period, are the subjects of the paper, which allows authors to set appropriate relations between the city of Murcia and its periurban territory, to afford the globalization age.
\end{abstract}

Keywords: Huerta de Murcia, non-planned occupation, territorial configuration.

\section{Introduction}

Certain peri-urban agricultural territories, located mainly around cities with a high demographic growth and intense migratory flows, have been altered in recent decades by a process of dispersed occupation, mostly with isolated single housings but also other urban uses. The intensity and the morphological characteristics of this peri-urban transformation share some common characteristics: low control of urban planning prescriptions, high spontaneity and frequent self-construction. At present there is a lack of accurate knowledge of the processes of these transformations and of the resulting morphological patterns. The objective of this paper is to achieve a better understanding of the territory in transformation, so that a better urban planning could be developed, preserving the rural heritage.

This work is centered in the study of the process of informal occupation in the Huerta de Murcia, at southeast Spain. It is a phenomenon that can be appreciated especially since the 1950 s, reaching worrisome levels in the last decades of the XXth century. The process results in the old agricultural field fabrics becoming a rururbanized fabric, with a high rate of single housings rate, not guaranteed minimum urban standards and endangered 
viability of agricultural activities.

The method of this work begins with a global analysis of the entire Huerta de Murcia area is performed, divided into homogeneous landscape units. Later, a study is systematized by combining the orthophotographic series available in the Territorial Information System of the Region of Murcia (www.sitmurcia.es) and the cadastral cartographic data (www. sedecatastro.gob.es). Using both sources, and through operations in GIS software, a global image of all buildings in the Huerta is obtained in each of the historical periods, according to the different orthophotographs.

This methodology allows establishing qualitative and quantitative conclusions about the analyzed transformation. The specific aim of this paper is to show the results of the qualitative analysis together with those of the quantitative analysis. So, it is possible to characterize the different periods and stages, obtaining in each one of them graphical patterns and intensity data that allow conclusions to be drawn from each period.

The results of this work will help to reverse or, at least, paralize the unsustainable process of transformation towards a diffuse city (Indovina, 2000).

\section{Geographical and cultural context.}

La Huerta de Murcia is a region located around the city of Murcia, in the Southeast of Spain. It was set up as an agricultural environment in the Muslim colonization in 825 A.D., with the creation of a irrigation system of canals, started in a water dam over the Segura River, that run through the valley where it was founded the city of Murcia.

An agrarian landscape of great aesthetic, cultural and patrimonial values were created from the complex network of canals of irrigation (carrying the water to every plot and collecting the excess to lead it back to the river) with allows facing the climatic adversity characterized by aridity and torrential rains. There are numerous studies of the Huerta de Murcia in the last 40 years, firstly from the fields of geography (Calvo, 1972; Zapata et alt., 1975; Andrés, 1987) and more recently from urbanism (Roselló y Cano, 1975; Cano, 2009; Ros and Garcia, 2016).

The urban - rural duality has remained for more than 1000 years, during which a slow and continuous process of transformation has taken place in. Until the middel of the last century, the rural component linked to the agriculture activity was dominant. Howewver, since the 1960 s, begin to occur two actions that tilt the balance toward the urban component.

The first of these actions is the unprecedented growth of the planned urban land of the city of Murcia and the pleiad of urban areas that are also located in the valley. These new growths multiplied the urban land of the existing city, with more than a thousand years, in just a few decades. This is, undoubtedly, a phenomenon similar to thus happened in mayority of Spanish cities at the time, due to the migrations from rural to urban areas, as well as the spectacular population growth linked to the improvement of economical, social and political conditions.

The second action has its origin in a slow, almost invisible but inexorable process, motivated by the change of habits of life of citizens. The residents in the city liked to get out of it and with private vehicles, find in the area of the Huerta de Murcia a place to its residence, a few minutes from the city, with lower land prices than in the planned lowdensity urbanizations and possibilities of a bigger contact with the natural environment.

The described area of the Huerta de Murcia is immersed in a wider territory of continuous irrigated lands associated with the valleys of Segura and Guadalentín rivers, which make up one of the most extensive areas of traditional peri-urban agricultural lands in Spain.

There are few studies to date that have analyzed this phenomenon in its entirety, although some of them do so in part, and can be compared with similar studies in other European areas (Calvo, 1972; Ferrario, 2009; Entrena, 2005).

\section{Agrarian morphology and landscape units.}

Once the region has been contextualized, and prior to the explanation of the methodology of the work carried out, it is considered necessary 


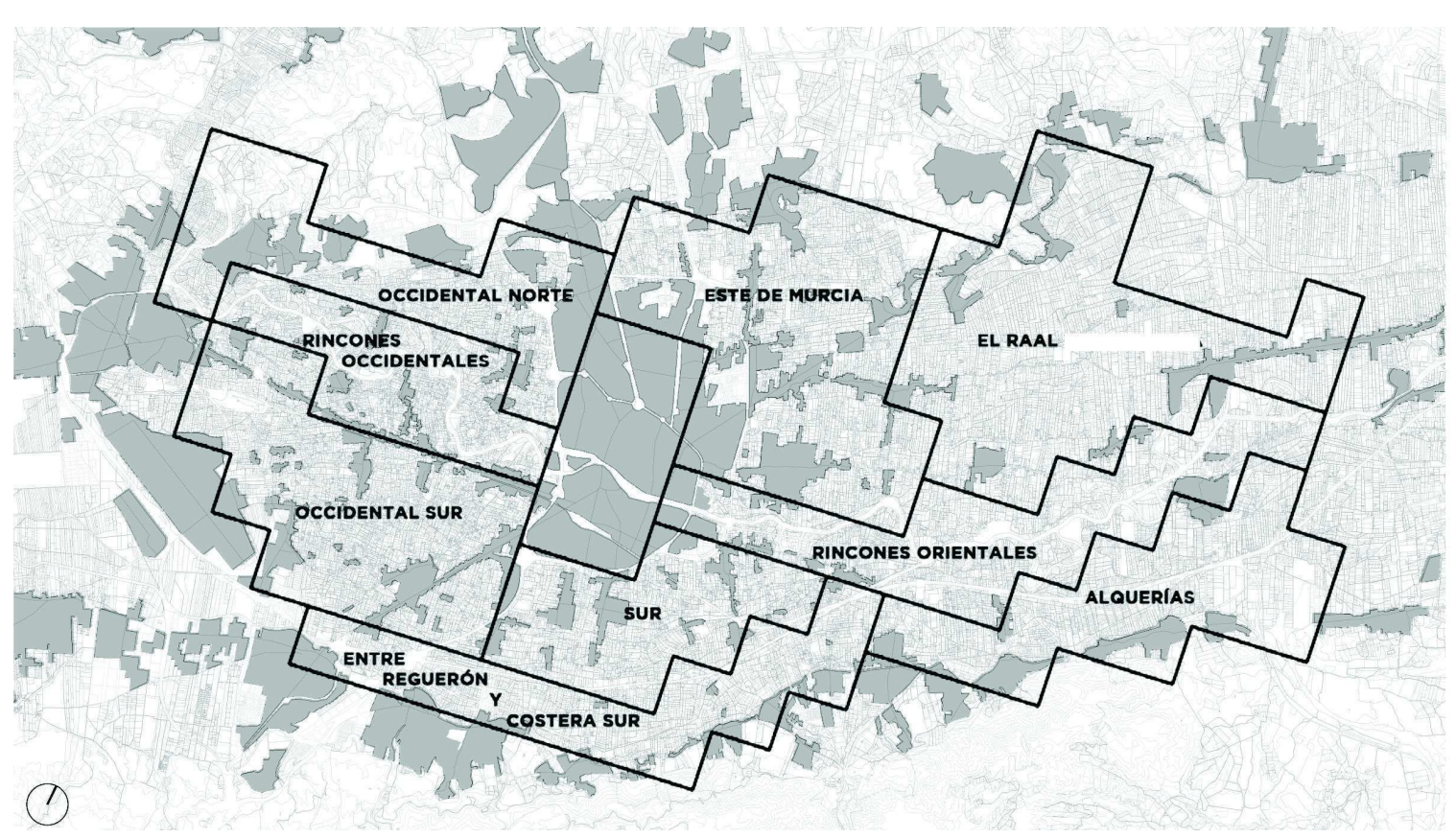

Figure 1.

Homogenous landscape units of the Huerta de Murcia, with urban nuclei in grey. Source: Ros y García, 2016.

to highlight the singularity of the agricultural morphology of the Huerta de Murcia. Contrary to habitual simplifications of the Huerta, there are different landscapes coexisting in the valley, wich have been considered in this work.

The agrarian morphology currently present in the Huerta de Murcia is derived from a long process of transformation, from its beginnings in the 9th century. Geographical studies (Calvo, 1972) have usually divided Huerta into three morphologically differentiated areas, due to different factors.

The Landscape Strategy of the Region of Murcia (2011), has defined fifteen homogeneous landscape units within the landscape area called Huerta de Murcia. These units are based on a previous study by Mata and Fernández (2004). For each unit the constituent elements are established: geoforms, hydrography, vegetal cover, land uses, elements of the agrarian structure, settlements, and road network; as well as quality indicators. From these elements, values of quality and fragility of the landscape are obtained.

In this work, the landscape units have been used because they include in its definition the form of the agricultural plots, which also have a strong role to determine the single housing occupation as well as the urban planning regulations.

\section{Methodology}

The first phase of the work was done as a pilot study case (Ros and García, 2012), analyzing a west fragment of the Huerta. This first phase served as a basis for exploring the methodological techniques to study the patterns and causes that had marked the transformation of the Huerta de Murcia.

This pilot study was carried out on the available orthophotographic series, and afterwards, and manually, the construction and plots were associated with each of the studied periods. Once all the data were extracted, the surfaces were numerically analyzed by periods and urban patterns were searched.

The second phase of the project has extended the scope of study to the entire Huerta de Murcia, within the limits defined historically, from its beginning in the Contraparada dam to the Vereda Real path, which is the boundary with the province of Alicante. In this global study we have analyzed the process of recent transformation of the traditional agricultural 


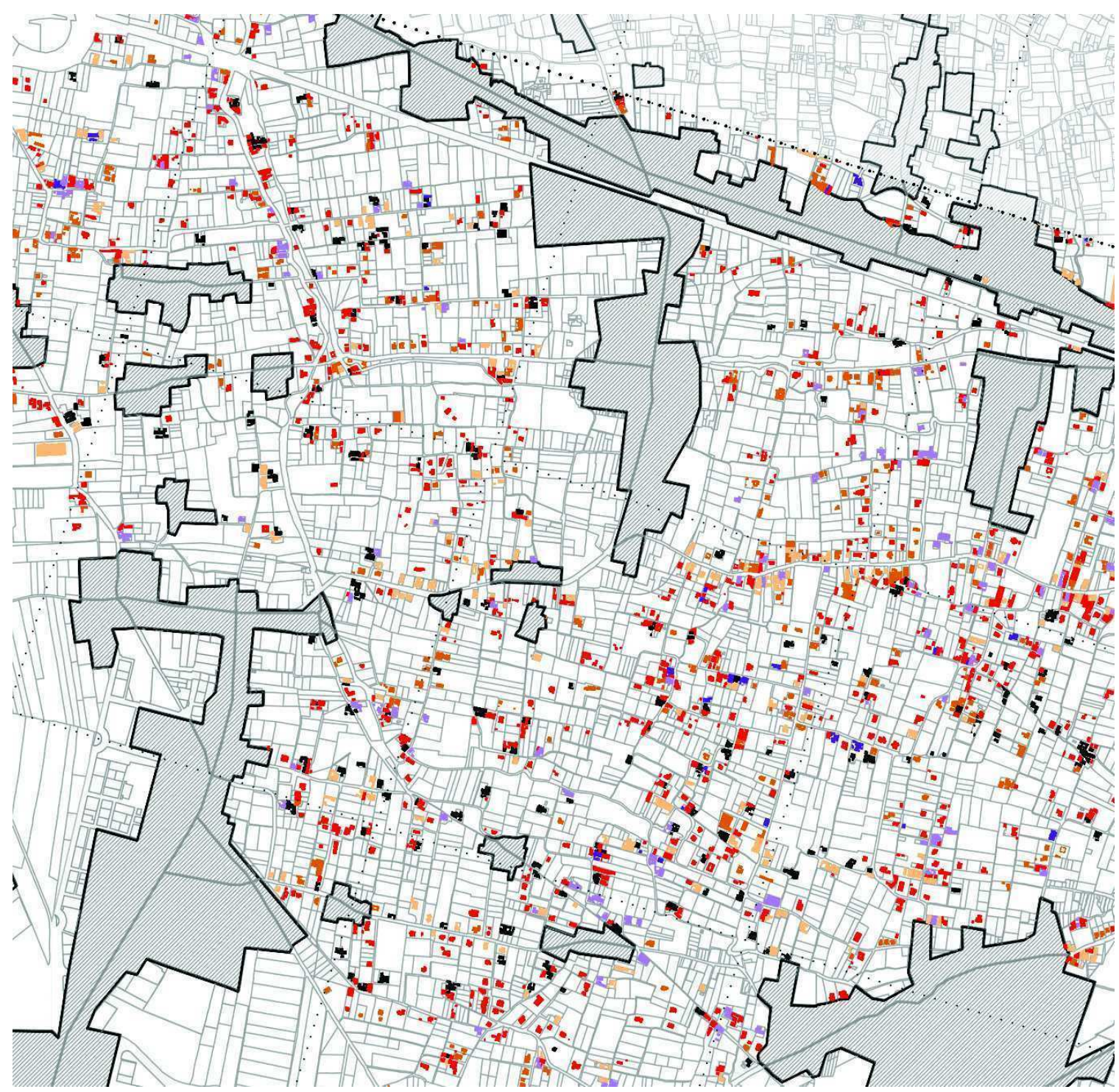

Figure 2.

Construction in a fragment of the Huerta de Murcia classified by period. Source: Ros y García, 2016.

fabric of the whole Huerta de Murcia, excluding only the present urban areas.

The exclusion of the urban areas leave out the "substitution" of the agrarian plots with new urban fabric, focusing the study only in the "transformation" over the agricultural fabric by the construction of housing buildings.

Once the area of study has been delimited, the methodology of work has been the following one:

-Download of orthophotographs of the study area from years 1928, 1946, 1956, 1981, 2002 and 2015.

-Download of cadastral cartography corresponding to the study area, including as a significant data the height of the constructions and obtaining by GIS software the plot area, the footprint area and the built area.

-Integration of both cartographies, and date assignation to each cadastral construction (verifiyng its fidelity to reality) to the oldest ortophography in which this construction appears in.

-Extraction of cartographies with the constructions existing in each ortophotography that remains till ourdays, distinguishing the ones that appear in the period till the previous ortophotography.

-Extraction of quantitative data, creation of data tables and graphs.

With the results of the previous steps, it was done a quantitative analisys of the occupied 


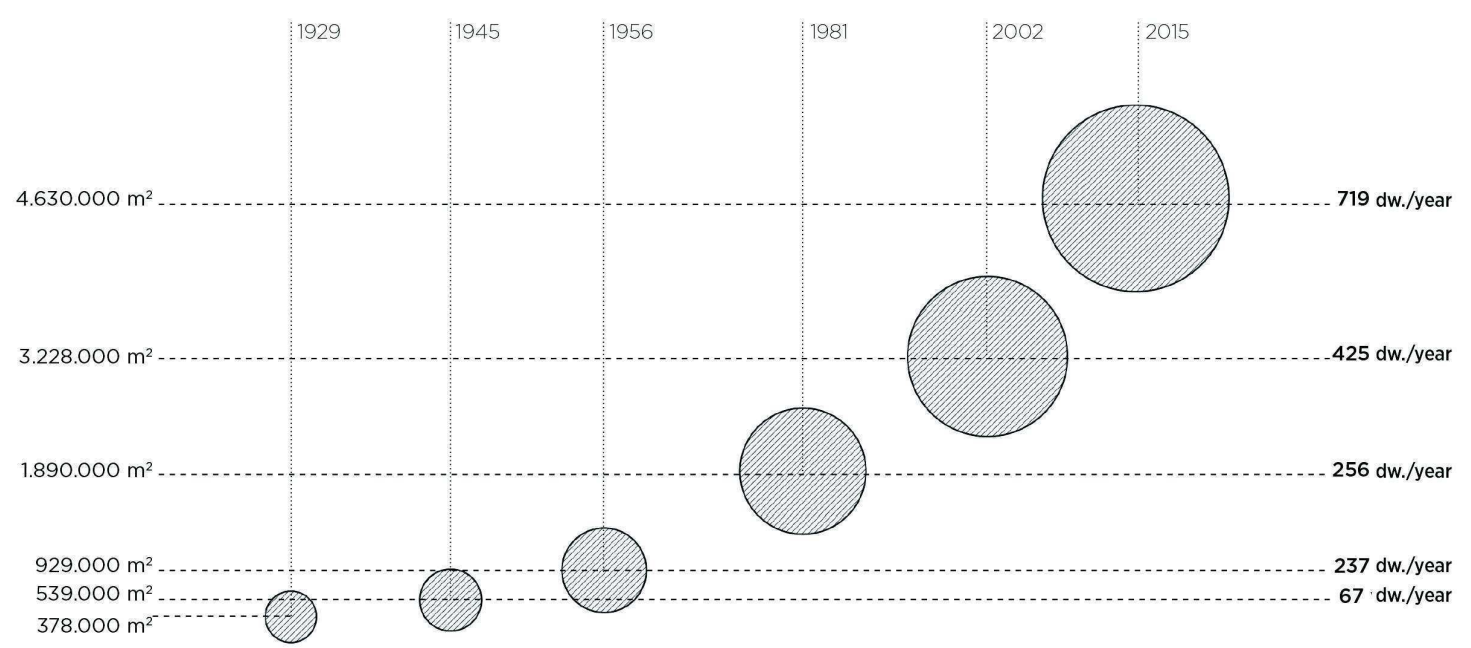

Figure 3.

. Quantitative evolution of the occupation in the Huerta de Murcia. Source: Ros y García, 2016.

area in each period. Under the hypothesis that the process had not had the same intensity in all the areas, the surface of the Huerta was divided into different fragments:

-A grid of $1 \times 1 \mathrm{~km}$ cells, the one used by Eurostat (http://ec.europa.eu/eurostat/ statistics-explained/index.php/Population grids) that allows a direct comparison between cells, being all of the same size.

-A serie of homogenous landscape areas, formed by the union of the previous cells, that correspond with the units defined in the Landscape Strategy of the Region of Murcia (2011) for the landscape of the Huerta de Murcia.

The last part of the method found, through subjective analysis of plans with the constructions of the different periods, growth patterns in the different periods and areas of the Huerta.

\section{Quantitative results of the occupation process.}

The most relevant data extracted from the global study are:

-The total footprint area of the constructions scattered in the peri-urban agricultural area of the Huerta de Murcia increased from 291.946 $\mathrm{m} 2$ in 1929 , to $3.643 .865 \mathrm{~m} 2$ in 2015 , more than 12 times the initial occupation.

-The built area (considering the different heights of the constructions) grew up from $378.928 \mathrm{~m} 2$ in 1929 to $4.630 .297 \mathrm{~m} 2$ in 2015 , also more than 12 times the initial area. The growth rate of each year over the previous one, calculated by interpolation of the periods, remains constant around $3.4 \%$. However, as these buildings accumulate, these percentages represent larger and larger quantities: from $10.000 \mathrm{~m} 2$ built each year between 1929 and 1945 , to an annual increase of $107.800 \mathrm{~m} 2$ built between 2002 and 2015 (area enough for about 1000 houses).

-The growth of the built area can also be analyzed as an estimation of the number of dwellings. To do this, instead of applying the usual ratio of $100 \mathrm{~m} 2$ per dwelling in the urban areas, they were used two ratios of $150 \mathrm{~m} 2$ and $200 \mathrm{~m} 2$ per dwelling, more representative of the typology of isolated single-family dwellings existing. Both data, compared with the number of plots with some type of construction obtained from the previous analysis; allow observing that there is a continuous growth in the rhythm of construction. Starting at about 50 dweeling per year in the period 1929-1945, the growth increases until an approximate balance of about 500 dwelling per years in the period 2002-2015, that is, a rate ten times higher than the initial one.

-The floor space index in the Huerta (excluding urban nuclei) has reached values of $0,076 \mathrm{~m} 2 / \mathrm{m} 2$ in the Huerta Sur, $0,068 \mathrm{~m} 2 / \mathrm{m} 2$ in Rincones Occidentales and $0,056 \mathrm{~m} 2 / \mathrm{m} 2$ in 
Huerta Sur. However, areas such as Huertas de Alquerías barely reach $0,0182 \mathrm{~m} 2 / \mathrm{m} 2$.

-It must be highlighted that, despite the apparent "saturation" of some traditional Huerta areas, in the last period, 2002-2015, the increase is still slightly higher each year compared to the previous one in all areas, even the most saturated.

-The relationship between footprint areas and built areas remains constant in practically all the series analyzed. The value of this ratio (built area/footprint area) is around 1.26-1.28.

The main purpose of this paper is to show a characterization of the different stages of the occupation of the Huerta de Murcia, both quantitatively and qualitatively (patterns) so that each phase can be understood in itself and in its importance in the configuration of the current morphology.

\section{Characterization of the different stages.}

The main purpose of this paper is to show a characterization of the different stages of the occupation of the Huerta de Murcia, both quantitatively and qualitatively (patterns) so that each phase can be understood in itself and in its importance in the configuration of the current morphology.

$$
\text { 1929-1945-1956. }
$$

The period is divided quantitatively into two phases. In the first phase from 1929 to 1945 , exists an annual rate of built area of $9.997 \mathrm{~m} 2$, which is equivalent to an annual rate of new dwelleings that barely reaches 50 units. In the second phase, from 1945 to 1956 , a rate of
$35.485 \mathrm{~m} 2$ was built each year, equivalent to 177 dwellings built per year.

Regarding the morphological patterns, the constructions in 1929 were located along two differentiated linear elements: the main roads and the main irrigation canals. Almost three decades later, in 1956, there are very moderate growths located mainly along the main roads. However, some areas of homogeneous dispersion begin to appear in the western Huerta.

Therefore, this period can be characterized as "low intensity, low dispersion and predominant linear pattern".

1956-1981.

Quantitatively this is a period in which there is a stabilization of the new built area rates, reaching $38.438 \mathrm{~m} 2$ built per year (around 319 new dwellings), which is similar to the rates of the second phase of the previous period.

With these rates of occupation, in the 25 years till 1981 the presence of dwellings was very important. They followed patterns of locations of homogenous dispersion at the west and south of the city. At East, however, the dweelings were built along secondary roads, perpendicual to the primary.

The characterization of this period is of "medium intensity, high dispersion, and secondary linear patterns".

\section{1-2002.}

The numerical data reflect a significant increase of the occupation rate, reaching $63.720 \mathrm{~m} 2$ per year, about 319 dwellings.

The location patterns followed by the new

Table 1. Built area and new dweelings annual rates for periods.

\begin{tabular}{|c|c|c|c|c|c|c|}
\hline \multirow{2}{*}{ Period } & \multirow{2}{*}{$\begin{array}{c}\begin{array}{c}\text { Built área } \\
\text { annual rate. }\end{array} \\
m^{2}\end{array}$} & \multicolumn{3}{|c|}{ New dweelings annual rate } & \multirow{2}{*}{$\begin{array}{l}\text { New } \\
\text { constructions } \\
\text { in the period. }\end{array}$} & \multirow{2}{*}{$\begin{array}{l}\text { New construction } \\
\text { annual rate. }\end{array}$} \\
\hline & & $100 \mathrm{~m}^{2} / \mathrm{dw}$ & $150 \mathrm{~m}^{2} / \mathrm{dw}$ & $200 \mathrm{~m}^{2} / \mathrm{dw}$ & & \\
\hline $1929-1945$ & 9.997 & 100 & 67 & 50 & 927 & 51,5 \\
\hline $1945-1956$ & 35.484 & 355 & 237 & 177 & 2.059 & 187,2 \\
\hline $1956-1981$ & 38.438 & 384 & 256 & 192 & 3.469 & 138,8 \\
\hline $1981-2002$ & 63.720 & 637 & 425 & 319 & 3.593 & 171,1 \\
\hline $2002-2015$ & 107.849 & 1.078 & 719 & 539 & 5.996 & 461,2 \\
\hline
\end{tabular}



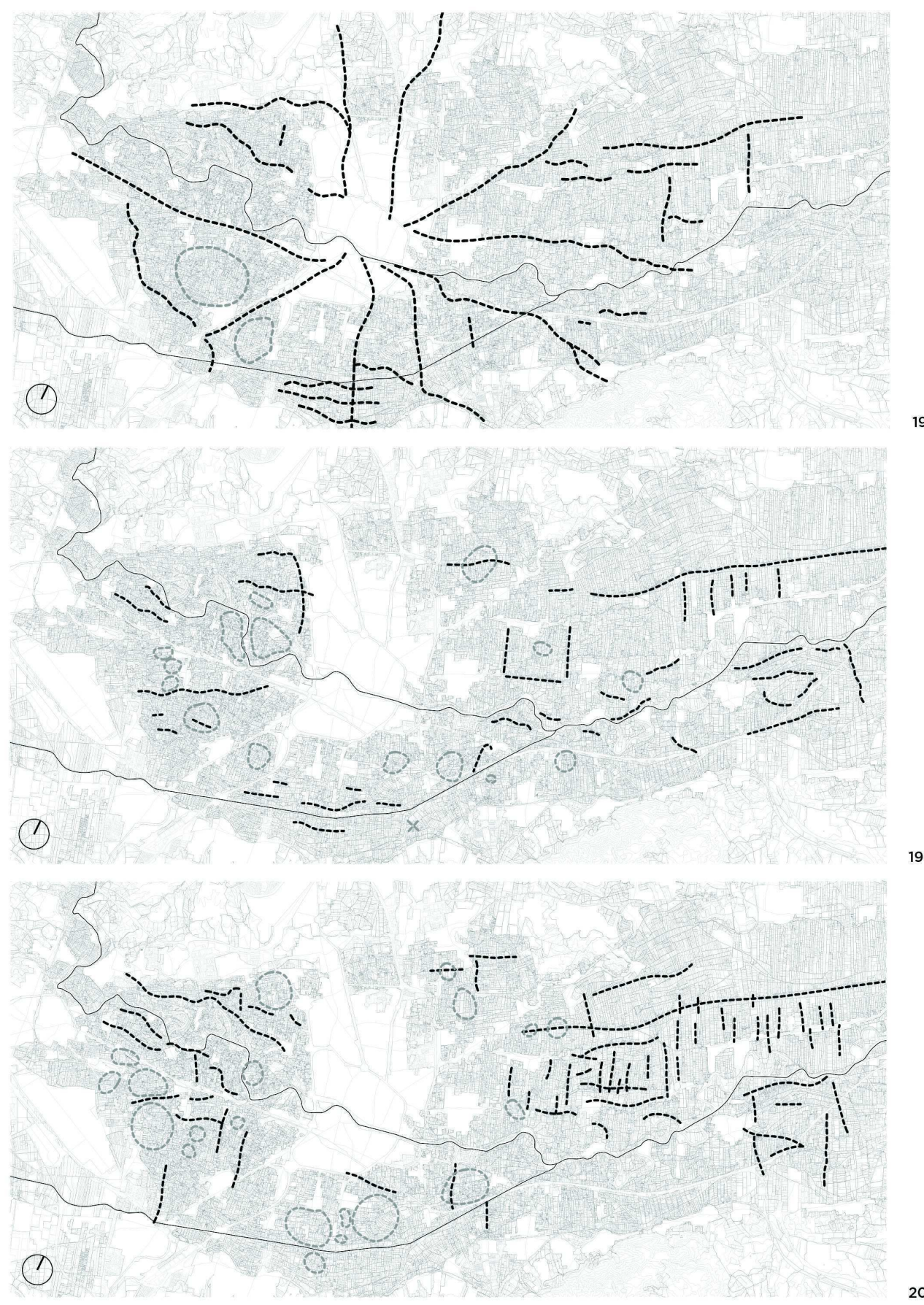

Figure 4.

Location patterns of new dwellings in 1929, 1982 and 2002. Source: Ros y García, 2016.

housings were diverse in this period, as they needed to search for new areas in a territory highly saturated of constructions. So thus, new dweelings with linear patterns appeared in a second line of the main roads at east Huerta and in secondary or even terciary roads in the west. In respect to the dispersed patterns, some wide areas of homogenous dispersion can be observed in the south of the city (instead of the west, were the saturation avoid this pattern).

This period is characterized as "high intensity, high dispersion and mixed saturation patterns" 
2002-2015

Again, there is another qualitative increas of the intensity of the occupation, reaching the annual rate of built area value of 107.849 $\mathrm{m} 2$, which triggers the new dwellings up to 539 per year. As it was mentioned, this means a multiplication by more than ten in relation to the values of the first section of the period 1929-1945.

The occupation patterns in this period were a strong combination of disperse and linear in almost of the areas in the Huerta de Murcia. The study, therefore, is reoriented in this last period, analyzing the portions of "productive Huerta" that have survived until 2015. These portions become a keystone for the future of the agrarian root of a highly saturated landscape, as they preserved the productive, cultural and etnographical values of the historic Huerta.

These portions of productive land are a series of isolated areas, of smaller size in the West and the South Huerta and larger in the East. Their conservation can serve as a basis for urban, ecological, social and patrimonial project strategies for Huerta de Murcia.

The final characterization of this last period corresponds to "very high intensity, very high dispersion and high combination of patterns".

\section{Resulting morphology in the Huerta de Murcia.}

The study has also identified up to 6 different forms of dwelling grouping in the agricultural plot of the Huerta, resulting of the overlapping of the different patterns described:

1.Rectangular cells of occupation in the East Huerta, next to the urban nucleus of Murcia. Based on the layout of the agrarian plot fabric, more geometric and regular than the existing in the West, the dwellings occupy the main roads in West to East direction and the secondary ones that cross them perpendicularly, preserving in their interior groups of agricultural plots. In the areas closest to the city, the dwellings also occupy these interior spaces in a dispersed and homogeneous pattern.

2. Fishbone structures along the main roads the East Huerta, closer to the border with
Alicante, and in the Huerta Sur. The most important communication routes of the valley (note those of Orihuela, Algezares, Santo Ángel and La Alberca) concentrated buildings linearly. The saturation of this roads caused that the perpendicular paths that arise from them are occupied also by constructions, forming a structure in fishbone.

The densification of some of these structures has formed urban nuclei with similar lineal structure: El Raal, Barrio del Progreso, San Benito...

3.Irregular cells in the west Huerta conformed by buildings along its perimeter roads, of irregular layout, and bags of agricultural parcels in its interior. As in the eastern part, in the areas closest to the city of Murcia the interior of these cells is also occupied by houses and other constructions in a dispersed way.

4.Isolated mixed structures. In the Rincones del Segura area, close to the river in the west, there are unique situations where the meanders form areas delimited by the river. In these areas, the clear boundary that establishes the river causes that several linear groups and some small nuclei of population mix each other to conform complex structures which are linked in several points to the main roads of the Nora and El Palmar roads.

5. Irregular permeable cells. In the Huerta Oeste, nearer to the city of Alcantarilla, the building also follows the main roads (La Nora, Camino Hondo and Albadel, as well as the old ways of Alcantarilla and Aljucer) and forms irregular cells, but with a lower intensity . Thus, these cells have a lower level of consolidation of the perimeter buildings, allowing a greater permeability with the agricultural bags inside.

6.Finally, it must be comented that in the Huerta de Murcia exists also point patterns of occupation, mainly located at road crossings. The elementary groups of houses built in the first century in this way, grew up forming many of the small urban nuclei currently considered as urban. Due to this urban character and the completly sustitution of the agricultural plot fabric, these environments have been left out of research. 

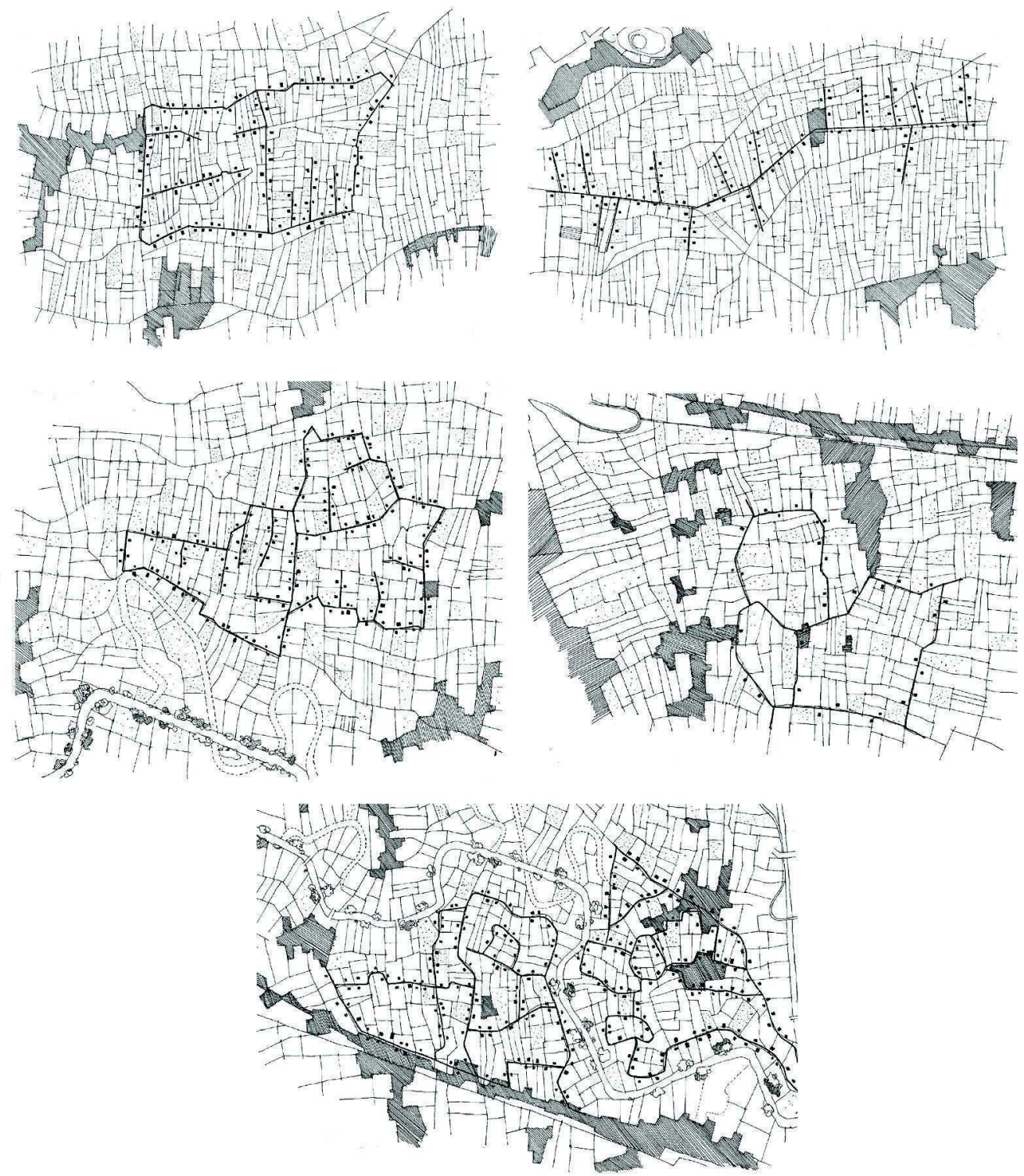

Figure 5.

Resulting morphology schemes of construction occupation. From left to right and up to bottom: rectangular cells, fishbone structures, irregular cells, irregular permeable cells and isolated mixed structures, irregular permeable cells. Source: Ros y García, 2016.

\section{Conclusion}

The conclusions of the quantitative analysis and the morphological qualitative situations give the following conclusions:

1.The dispersed occupation of the periurban territory of the Huerta de Murcia is a spontaneous model result of individual actions of citizens from the near urban centers, who establish their new residence in the area.

2.It is a model of occupation sustained over time, that, since 1929, has not known any period of recession o slowdown.
3.Although the different periods defined responds to the availability of orthophotos, it is clear that each ofne reflects different values in occupation, dispersion and patterns. So thus, it is possible to characterize each one of them according with this parameters.

4.In spite of being a spontaneous process, not regulated in the urban planning, the study have revealed that exists some patterns in the location of new constructions that define each period: 
a)occupation at the edge of main roads of agricultural fabrics,

b)occupation at the edge of secondary roads and canals,

c)occupation in a second line of the main roads (besides the first dwellings in the edge),

d)occupation in small punctual nuclei, at the intersection of main roads,

e)areas of homogeneous dispersion (mainly in the west and south areas of the Huerta),

5.The overlapping of these different patterns of occupation in time and space define the present morphology of the rururbanized territory of the Huerta de Murcia. Five differents types of forms have been found and defined: Rectangular cells, fishbone structures, irregular cells, isolated mixed structures, irregular permeable cells.

\section{References.}

Andrés Sarasa, J. L. (1987). El área periurbana de Murcia. Incidencias demográficas, financieras y espaciales. (EDITUM, Ed.). Murcia.

Calvo García-Tornel, F. (1972). La formación del paisaje agrario de la huerta de Murcia. Revista de Geografía, (6), 5-33.

Cano Clarés, J. L. (2009). El Plan General de Murcia de 1978. La implantación práctica del urbanismo contemporáneo. Universidad Politécnica de Valencia.

Entrena Durán, F. (2005). Procesos de periurbanización y cambios en los modelos de ciudad Un estudio europeo de casos sobre sus causas y consecuencias. Papers: Revista de Sociología, 78, 59-88.

Ferrario, V. (2009). Agropolitana. Dispersed city and agricultural spaces in Veneto region (Italy). The 4th International Conference of the International Forum on Urbanism (IFoU). The New Urban Question - Urbanism beyond Neo-Liberalism, 637-646.

Indovina, F. (2000). La ciudad difusa. In Edicions UPC (Ed.), Lo urbano en 20 autores contemporáneos (pp. 49-59). Barcelona.

Mata Olmo, R., \& Fernández Muñoz, S. (2004). La Huerta de Murcia: Landscape Guidelines for a Peri-urban Territory. Landscape Research \& Landscape Research
Extra, 29(4), 385-397.

Roselló Verger, V., \& Cano García, G. M. (1975). Evolucion urbana de la ciudad de Murcia. 831-1973. Murcia: Ayuntamiento de Murcia.

Ros Sempere, M., \& García Martín, F. M. (2012). Análisis de la transformación de usos del suelo en la Huerta de Murcia : etapas, patrones de transformación y causas. In CONAMA 2012 Congreso Nacional de Medio Ambiente (p. 27). Madrid.

Ros Sempere, M., \& García Martín, F. M. (2016). Cinco palmos 1929-2015. Transformación de usos del suelo en la Huerta de Murcia (1st ed.). Murcia: CRAI Biblioteca - Universidad Politécnica de Cartagena.

Zapata Nicolás, M., Sempere Flores, A., \& Calvo García-Tornel, F. (1975). El terreno fértil como recurso escaso. Un ejemplo de despilfarro: La huerta de Murcia. Revista de Estudios Agrosociales, (90), 189-204. 